\title{
Patients with Prolonged Positivity of SARS-CoV-2 RNA Benefit from Convalescent Plasma Therapy: A Retrospective Study
}

\author{
Yongran $\mathrm{Wu}^{1} \cdot \mathrm{Ke} \mathrm{Hong}{ }^{2} \cdot$ Lianguo Ruan ${ }^{2} \cdot$ Xiaobo Yang ${ }^{1} \cdot$ Jiancheng Zhang ${ }^{1} \cdot$ Jiqian $\mathrm{Xu}^{1} \cdot$ Shangwen Pan ${ }^{1} \cdot$ \\ Lehao Ren ${ }^{1} \cdot$ Lu Chen $^{2} \cdot$ Chaolin Huang $^{2}$ (]) You Shang ${ }^{1}$ (C)
}

Received: 9 July 2020 / Accepted: 3 August 2020 / Published online: 31 August 2020

(c) Wuhan Institute of Virology, CAS 2020

\begin{abstract}
Convalescent plasma therapy has been implemented in a few cases of severe coronavirus disease 2019. No report about convalescent plasma therapy in treating patients with prolonged positivity of SARS-CoV-2 RNA has been published. In this study, we conducted a retrospective observational study in 27 patients with prolonged positivity of SARS-CoV-2 RNA, the clinical benefit of convalescent plasma therapy were analyzed. qRT-PCR test of SARS-CoV-2 RNA turned negative ( $\leq 7$ days) in a part of patients (early negative group, $n=15$ ) after therapy, others (late negative group, $n=12$ ) turned negative in more than 7 days. Pulmonary imaging improvement was confirmed in 7 patients in early negative group and 8 in late negative group after CP therapy. Viral load decreased in early negative group compared with late negative group at day 3,5, 7 after implementing convalescent plasma therapy. Patients in early negative group had a shorter median length of hospital stay. In conclusion, convalescent plasma therapy might help eliminate virus and shorten length of hospital stay in patients with prolonged positivity of SARS-CoV-2 RNA.
\end{abstract}

Keywords Coronavirus disease 2019 (COVID-19) · SARS-CoV-2 · Prolonged positivity · Convalescent plasma therapy

\section{Introduction}

The severe acute respiratory syndrome coronavirus 2 (SARS-CoV-2) emerged in late 2019 (Zhu et al. 2020), has been rapidly spreading and causing a worldwide pandemic (Kirby 2020; Saglietto et al. 2020). The pneumonia induced by SARS-CoV-2 is known as coronavirus disease 2019 (COVID-19) (Ivers and Walton 2020). To date, the virus has infected millions of people all over the world.

Yongran $\mathrm{Wu}, \mathrm{Ke}$ Hong and Lianguo Ruan contributed equally to this work.
You Shang
you_shanghust@163.com
$\triangle$ Chaolin Huang
chaolin2020@163.com

1 Department of Critical Care Medicine, Union Hospital, Tongji Medical College, Huazhong University of Science and Technology, Wuhan 430022, China

2 Research Center for Translational Medicine, Jinyintan Hospital, Wuhan 430022, China
Recently, many studies about long-term viral duration in COVID-19 patients have been published (Liu et al. 2020; Wan et al. 2020; Zhou et al. 2020; Shi et al. 2020; Yang JR et al. 2020; Li et al. 2020). The longest duration observed was 83 days in one patient's upper respiratory tract samples ( $\mathrm{Li}$ et al. 2020). Although the association between viral duration and disease severity or older age was inconsistent in different studies, some studies reported longer viral duration correlated with severe disease or older age in COVID-19 patients (Yan et al. 2020; Zhang YC et al. 2020; Hu et al. 2020). Besides, there are limited evidences about the infectivity of SARS-CoV-2 for patients with prolonged positivity of SARS-CoV-2 RNA (Walsh et al. 2020). Thus, treating prolonged positive patients might be necessary during this COVID-19 pandemic.

By now, no anti-viral therapy has been proven effective in treating COVID-19. Convalescent plasma (CP) therapy is a classical passive antibody therapy used to treat viral pandemic historically, such as influenza A (HIN1) (Hung et al. 2011), Ebola virus disease (Sahr et al. 2017) and SARS (Cheng et al. 2005). Recently case reports showed that $\mathrm{CP}$ collected from recovered patients might be effective to treat critically ill patients with COVID-19 (Zhang B 
et al. 2020; Ahn et al. 2020; Duan et al. 2020; Shen et al. 2020). However, in these studies, critically ill patients at the early stages of illness were mainly aimed. There is not any report about implementing $\mathrm{CP}$ therapy in patients with prolonged positivity of SARS-CoV-2 RNA.

We noticed that convalescent plasma was sometimes given to these patients with prolonged positivity of SARSCoV-2 RNA. Herein, we perform a retrospective study to analyze the clinical benefit of CP therapy in patients with prolonged positivity of SARS-CoV-2 RNA.

\section{Materials and Methods}

\section{Design and Study Participants}

This single-center retrospective observational study was performed in Jinyintan Hospital, which is one of the earliest designated hospitals for COVID-19 in Wuhan, China. Patients who confirmed COVID-19 admitted into Jinyintan Hospital from January 1 to April 20, 2020, were included for initial screen. We investigated all patients with COVID-19 who received CP therapy during hospitalization without enrolled in any other random control trial. Patients were excluded if their SARS-CoV-2 tests were negative before infusion of CP. The clinical outcomes (discharges, mortality, length of hospital stay) were monitored up to April 25, 2020. The discharged patients in Jinyintan Hospital must need to meet the following criteria: patients with two consecutive negative tests of respiratory specimens; patients' symptom resolved; no hospitalization was required as assessed by clinicians. In our study, all discharged patients still need to transport to other isolation sites for medical observation for 2 weeks.

In our study, we defined patients with tests of SARSCoV-2 turned negative $\leq 7$ days after the first infusion of $\mathrm{CP}$ to be in early negative group (EN group), others were defined to be in late negative group (LN group).

\section{Clinical Information}

Clinical information of patients was collected from the electronic medical information system of Jinyintan Hospital, including the following factors: demographic data; date of symptom onset, admission, first CP infusion and discharge; laboratory data before and after infusion of $\mathrm{CP}$, including white blood cell count, neutrophil count, lymphocyte count, liver and kidney function test, and inflammatory factors such as high sensitive C-reaction protein (HsCRP); results of SARS-CoV-2 test and cycle threshold value ( $\mathrm{Ct}$ value) of quantitative reverse transcription-polymerase chain reaction; patients' status and treatments before or after the $\mathrm{CP}$ therapy, including the vital signs, anti-virus therapy, oxygen therapy, and other treatments; total volume dose of $\mathrm{CP}$; pulmonary imaging examination data; information on complications such as transfusion-related adverse reactions.

\section{Quantitative Reverse Transcription-Polymerase Chain Reaction}

Test of SARS-CoV-2 were performed in a laboratory in Jinyintan Hospital. Respiratory tract specimens (including nasopharyngeal, sputum, bronchial alveolar lavage fluid) collected from patient were transferred to the laboratory within $4 \mathrm{~h}$. The quantitative reverse transcription-polymerase chain reaction (RT-PCR) of SARS-CoV-2 has already been described previously (Corman et al. 2020). Total nucleic acid extraction was performed on the specimens using the RNA Viral Kit (Life River). The $E$ gene, $N$ gene, and RdRP gene of SARS-CoV-2 (located in ORFlab reading frame) was detected using a specific kit (Life River), which was approved by the China Food and Drug Administration. Ct value is the number of cycles required for the fluorescent signal to cross the threshold for a positive test, and a higher $\mathrm{Ct}$ value is correlated with lower viral load. According to the instruction of the kit, $\mathrm{Ct}$ values of specimens with $E$ gene, $N$ gene, and $R d R P$ gene $<43$ were considered to be positive, and results were highly reliable.

\section{Artificial Intelligence Analysis of Computed Tomography}

The imaging artificial intelligence (AI)-assisted diagnostic system can quickly identify COVID-19, delineate and quantify lesions designed by the Chinese Academy of Sciences, National Biological Information Center, Tsinghua University, and Hospital of Zhongshan University. It is developed by applying advanced AI technologies, such as deep learning, transfer learning, and using the multiple neural network architecture training models. Besides AI, X-ray and computed tomography (CT) images of all patients have been manually reviewed by a group, consisting of three experienced imaging specialists.

\section{CP of Donors}

All CP were obtained from donors recovered from COVID-19, the interval between symptom onset and donation of donors were $>3$ weeks; all donors must meet the discharge standard of the seventh Trial Version of the New Coronavirus Pneumonia Prevention and Control Program (Chinese National Health Commission 2020). All the donors were confirmed without transfusion-related infectious diseases before donation. Interval between 
discharge and donation must be $>10$ days. The neutralizing antibody titer was evaluated before transfusion, convalescent plasma with titer of $>1: 160$ were used for patients in our study. After the clinician applying for a blood transfusion, convalescent plasma would be transferred from the blood center to the isolation ward on the same day.

\section{Statistical Analysis}

Data were expressed as categorical variable and continuous variable. To compare the EN group and LN group, Chisquare test was used to analyze the categorical variable. For the continuous variable, results of Data were shown as median and inter-quartile range (IQR). Mann-Whitney test was used to perform nonparametric test. A two-sided $P$ value $<0.05$ were considered statistically significantly different between the two groups. SPSS 22.0 is used for statistical analysis.

\section{Results}

\section{Demographics and Baseline Characteristics of Patients with Prolonged Positivity of SARS- CoV-2 RNA before CP Therapy}

As shown in Table 1, a total of 27 adult patients, with a median 44.0 (30.0-47.0) days between symptom onset and last positive test of SARS-CoV-2 RNA before CP therapy, were included. Their median age was 64.0 (57.0-72.0) years and $15(55.5 \%)$ patients were male.

We conducted a subgroup analysis between patients of EN group and LN group. Demographic data was shown as Table 1, median age, percentage of male patients, coexisting chronic diseases of patients in both groups were not significantly different (Table 1). Each patient of both groups underwent laboratory tests before $\mathrm{CP}$ therapy including white cell count, neutrophil count, lymphocyte count, platelet count, hematocrit, serum creatinine test, serum total bilirubin, serum alanine aminotransferase, serum aspartate aminotransferase, and hsCRP test, and the results were shown as Table 1.

As shown in Table 2, patients in both groups have a longer median interval between symptom onset and date of CP transfusion as compared to former reports [40.0 (26.0-47.0) days in EN group and 45.5 (41.2-57.0) days in LN group]. The median body temperature and oxygen therapy before $\mathrm{CP}$ transfusion were not significant different. The median fraction of inspiration $\mathrm{O}_{2}\left(\mathrm{FiO}_{2}\right)$, peripheral oxygen saturation and anti-viral therapies of both groups before CP therapy are shown in Table 2. Before transfusion, eight patients in EN group and seven in LN group received broad-spectrum antibiotic therapy, three patients in EN group and two in LN group received corticoid therapy after admission. Four patients in EN group and two in LN group received infusion of immunoglobulin after admission. As shown in Tables 1, 2, demographics and baseline characteristics of patients in EN group and LN group were not significant different before CP therapy.

\section{Clinical Benefit and Outcome of Patients with Prolonged Positivity of SARS-CoV-2 RNA after CP Therapy}

As shown in Table 3, the median and interquartile ranged total volume of CP transfusion was $400(200-400) \mathrm{mL}$ in EN group and 400 (400-800) $\mathrm{mL}$ in LN group. No adverse reactions related to blood transfusion were found during infusion in both groups. The median interval between transfusion and discharge was $7.0(4.0-11.0)$ days in EN group and 24.0 (14.7-28.7) days in LN group. Most patients underwent X-ray or CT scan before and after transfusion ( $\mathrm{EN}$ group $=8$; LN group $=12$ ), and pulmonary imaging improvement was confirmed in 7 patients in EN group and 8 in LN group after CP therapy.

The median length of hospitalization in EN group was 37.0 days and 52.0 days in LN group, as shown in Table 3. Due to the definition of EN group and LN group, the median length of hospitalization in LN group was much longer than EN group, thus we didn't make a comparative analysis. Three patients died in LN group within 60 days, two died from refractory hypoxemia and one in LN group died from severe septic shock. No patients died in EN group within 60 days.

\section{Comparison of Lung Imaging before and after CP Therapy in Patients with Prolonged Positivity of SARS-CoV-2 RNA}

Five patients in our study underwent $\mathrm{CT}$ scan before (within 3 days) and reexamination after transfusion (within 5-8 days). For these patients, comparison and analysis of CT images were performed before and after transfusion by using the AI-assisted diagnostic system described above (Fig. 1A, 1B). Three (60\%) patients showed as consolidation of CT images before CP therapy (Fig. 1C), five all showed as ground-glass opacity (GGO) (Fig. 1D) before CP therapy, which were similar to the former report about CT findings in COVID-19 patients (Adair and Ledermann 2020). After transfusion, the total consolidation percentage decreased after transfusion in three patients (Fig. 1C), and the total GGO percentage decreased in five all patients' CT images (Fig. 1D). 
Table 1 Demographic and clinical characteristics of patient before CP therapy.

\begin{tabular}{|c|c|c|c|c|}
\hline Characteristic & $\begin{array}{l}\text { Total } \\
\mathrm{n}=27\end{array}$ & $\begin{array}{l}\text { EN group } \\
\mathrm{n}=15\end{array}$ & $\begin{array}{l}\mathrm{LN} \text { group } \\
\mathrm{n}=12\end{array}$ & $P$ value \\
\hline Age, median (IQR)-y & $64.0(57.0-72.0)$ & $63.0(57.0-72.0)$ & $65.0(56.2-78.0)$ & 0.581 \\
\hline Male sex-no. $(\%)$ & $15(55.5)$ & $6(40)$ & $9(75)$ & 0.121 \\
\hline \multicolumn{5}{|l|}{ Coexisting chronic disease-no. $(\%)$} \\
\hline Hypertension & $12(44.4)$ & $6(40)$ & $6(50)$ & 0.707 \\
\hline Coronary artery disease & $2(7.4)$ & $1(6.6)$ & $1(8.3)$ & 1.000 \\
\hline Diabetes & $2(7.4)$ & $1(6.6)$ & $1(8.3)$ & 1.000 \\
\hline Malignant tumor & $3(11.1)$ & $2(13.3)$ & $1(8.3)$ & 1.000 \\
\hline Neurological disorders & $6(22.2)$ & $3(20)$ & $3(25)$ & 1.000 \\
\hline Chronic kidney disease & $1(3.7)$ & 0 & $1(8.3)$ & \\
\hline HIV/AIDS & $2(7.4)$ & 0 & $2(16.6)$ & \\
\hline Chronic liver disease & $2(7.4)$ & 0 & $1(8.3)$ & \\
\hline \multicolumn{5}{|l|}{ Laboratory tests before transfusion } \\
\hline White-cell count, median (IQR)- $\left(\times 10^{-9} / \mathrm{L}\right)$ & $5.37(4.81-7.99)$ & $6.49(4.81-7.99)$ & $4.16(3.31-7.47)$ & 0.075 \\
\hline Neutrophil count, median (IQR)- $\left(\times 10^{-9} / \mathrm{L}\right)$ & $3.57(2.58-5.58)$ & $4.25(2.94-5.70)$ & $2.83(1.91-4.26)$ & 0.083 \\
\hline Lymphocyte count, median (IQR)- $-\left(\times 10^{-9} / \mathrm{L}\right)$ & $1.24(0.62-1.85)$ & $1.44(0.46-1.85)$ & $1.07(0.64-1.33)$ & 0.614 \\
\hline Platelet count, median $(\mathrm{IQR})-\left(\times 10^{-9} / \mathrm{L}\right)$ & $175(137-194)$ & $185(163-219)$ & $148(78-183)$ & 0.054 \\
\hline Hematocrit, median (IQR)—(\%) & $33.4(28.4-38.4)$ & $33.4(26.4-40.1)$ & $34.1(28.7-38.3)$ & 0.943 \\
\hline Serum creatinine, median $(\mathrm{IQR})-(\mu \mathrm{mol} / \mathrm{L})$ & $69.1(57.4-75.0)$ & $66.0(56.0-75.0)$ & $70.5(59.0-112.0)$ & 0.683 \\
\hline Total bilirubin, median $(\mathrm{IQR})-(\mu \mathrm{mol} / \mathrm{L})$ & $11.4(8.6-18.0)$ & $11.9(9.4-18.0)$ & $10.8(8.1-20.0)$ & 0.648 \\
\hline Alanine aminotransferase, median $(\mathrm{IQR})-(\mathrm{U} / \mathrm{L})$ & $17.0(10.0-28.0)$ & $24.0(13.0-33.0)$ & $13.0(8.5-26.0)$ & 0.103 \\
\hline Aspartate aminotransferase, median (IQR)—(U/L) & $26.0(20.0-42.0 .0)$ & $27.0(21.0-60.0)$ & $24.5(15.5-34.5)$ & 0.516 \\
\hline High-sensitivity C-reactive protein, median $(\mathrm{IQR})-(\mathrm{mg} / \mathrm{L})$ & $3.1(0.8-37.8)$ & $3.1(0.8-38.1)$ & $3.9(0.7-42.8)$ & 0.733 \\
\hline
\end{tabular}

\section{Variation Trend of Viral Load before and after CP Therapy in Patients with Prolonged Positivity of SARS-CoV-2 RNA}

After admission, patients in both groups underwent SARSCoV-2 tests by using RT-PCR as described above. The variation trend of $\mathrm{Ct}$ value in both groups are show as Fig. 2. The median $\mathrm{Ct}$ value on admission is 33.0 (28.7-38.2) in EN group and 32.5 (22.1-38.1) in LN group, without significant differences $(P=0.591$, Fig. 2). Besides, the median $\mathrm{Ct}$ values was not significant between EN group and LN group before transfusion [34.0 (26.4-38.3) vs. 30.9 (26.7-35.7), $P=0.591$, Fig. 2]. After transfusion, Ct values of patients in EN group increased and $>43$ within 7 days gradually and most of them $(\mathrm{n}=13)$ discharged within 10 days and were unable to detect at 9, 12, and 15 days. Conversely, the median $\mathrm{Ct}$ values of patients in $\mathrm{LN}$ group remained $<43$ at 3, 5, 7, 9, and 12 days after transfusion, 6 patients in LN group still remained $<43$ at 15 days after transfusion (Fig. 2).

\section{Discussion}

Our study explored the efficiency of $\mathrm{CP}$ therapy in COVID-19 patients at a later stage of the illness. All patients with prolonged positivity of SARS-CoV-2 RNA in our study were implemented CP therapy including mild cases. We confirmed that the viral load rapidly decreased after CP therapy in some patients (EN group), whereas others remain positive 7 days after CP therapy (LN group). The difference in baseline information, viral load, and other interventions was not significant before transfusion. After CP therapy, more than half patients obtained a rapid decrease of viral load.

CP therapy is a classic therapy against pandemic that can be traced back to the early twentieth century and clinicians treated the 1918 Spanish influenza with convalescent sera (Luke et al. 2006), which was found to be effective in decreasing the mortality of 1918 Spanish influenza pandemic. In the 21 st century researches have shown that CP therapy effectively and safely treats H1N1 and SARS at the early stage of illness. Besides SARS and H1N1, there is also some anecdotal information on the use of convalescent serum in seriously ill individuals. Two 
Table 2 Patients' status and treatments received before CP therapy.

\begin{tabular}{|c|c|c|c|c|}
\hline Characteristic & $\begin{array}{l}\text { Total } \\
\mathrm{n}=27\end{array}$ & $\begin{array}{l}\text { EN group } \\
\mathrm{n}=15\end{array}$ & $\begin{array}{l}\mathrm{LN} \text { group } \\
\mathrm{n}=12\end{array}$ & $P$ value \\
\hline Interval between symptom onset and transfusion, median (IQR) - $d$ & $45.0(35.0-49.0)$ & $40.0(26.0-47.0)$ & $45.5(41.2-57.0)$ & 0.075 \\
\hline $\begin{array}{l}\text { Interval between symptom onset and last positive test before CP therapy, } \\
\text { median (IQR)—d }\end{array}$ & $44.0(30.0-47.0)$ & $39.0(24.0-45.0)$ & $44.5(38.2-54.7)$ & 0.126 \\
\hline Body temperature, median $(\mathrm{IQR})-{ }^{\circ} \mathrm{C}$ & $36.9(36.6-37.0)$ & $36.8(36.5-37.2)$ & $36.9(36.7-37.0)$ & 0.516 \\
\hline Fever-no. $(\%)$ & $6(22.2)$ & $4(26.6)$ & $2(16.6)$ & 0.662 \\
\hline \multicolumn{5}{|l|}{ Oxygen therapy-no. $(\%)$} \\
\hline No oxygen treatment & $19(70.3)$ & $10(66.6)$ & $9(75.0)$ & 0.696 \\
\hline Nasal catheter oxygen therapy & $3(11.1)$ & $3(20)$ & $0(0)$ & \\
\hline Mechanical ventilation & $5(18.5)$ & $2(13.3)$ & $3(25.0)$ & 1.000 \\
\hline Extracorporeal membrane oxygenation & $1(3.7)$ & $1(6.6)$ & $0(0)$ & \\
\hline Fraction of inspiration $\mathrm{O}_{2}(\mathrm{n}=26)$, median $(\mathrm{IQR})-\%$ & $21.0(21.0-33.0)$ & $21.0(21.0-33.0)$ & $21.0(21.0-35.2)$ & 0.809 \\
\hline Respiratory rate $>24$ times/min-no. $(\%)$ & $5(18.5)$ & $3(20)$ & $2(16.6)$ & 1.000 \\
\hline Peripheral oxygen saturation, median (IQR)—\% & $98.0(97.0-99.0)$ & $97.0(97.0-99.0)$ & $97.0(97.0-98.5)$ & 0.905 \\
\hline Vasopressors-no. (\%) & $4(14.8)$ & $1(6.6)$ & $3(25.0)$ & 0.294 \\
\hline \multicolumn{5}{|l|}{ Anti-virus therapy-no. $(\%)$} \\
\hline Ribavirin & $4(14.8)$ & $2(13.3)$ & $2(16.6)$ & 1.000 \\
\hline Lopinavir & $8(29.6)$ & $3(20.0)$ & $5(41.6)$ & 0.398 \\
\hline Favipiravir & $2(7.4)$ & $2(13.3)$ & $0(0)$ & \\
\hline Definite or suspected coinfection-no. (\%) & $6(22.2)$ & $3(20.0)$ & $3(25.0)$ & 0.433 \\
\hline Broad-spectrum antibiotic therapy-no. (\%) & $15(55.5)$ & $8(53.3)$ & $7(58.3)$ & 1.000 \\
\hline Corticoid therapy-no. $(\%)$ & $5(18.5)$ & $3(20)$ & $2(16.6)$ & 1.000 \\
\hline Immunoglobulin therapy-no. (\%) & $6(22.2)$ & $4(26.6)$ & $2(16.6)$ & 0.662 \\
\hline
\end{tabular}

Table 3 Patients' status after transfusion and outcome after CP therapy.

\begin{tabular}{llll}
\hline Characteristic & $\begin{array}{l}\text { Total } \\
\mathrm{n}=27\end{array}$ & $\begin{array}{l}\text { EN group } \\
\mathrm{n}=15\end{array}$ & $\begin{array}{l}\mathrm{LN} \text { group } \\
\mathrm{n}=12\end{array}$ \\
\hline Total volume dose of CP, median (IQR)—-mL & $400(200-600)$ & $400(200-400)$ & $400(400-800)$ \\
Transfusion-related adverse reactions—-no. (\%) & $0(0)$ & $0(0)$ & 0.861 \\
Interval between first transfusion and discharge, median (IQR)—d & $11.0(6.0-25.0)$ & $7.0(4.0-11.0)$ & $24.0(14.7-28.7)$ \\
Pulmonary imaging improvement & $15 / 20$ & $7 / 8$ & $8 / 12$ \\
Length of hospital stay, median (IQR)—d & $43.0(24.0-54.0)$ & $37.0(19.0-50.0)$ & $52.0(35.0-63.7)$ \\
Mortality of 60 days-no. $(\%)$ & $3(11.1)$ & $0(0)$ & $3(25)$ \\
\hline
\end{tabular}

patients diagnosed with Ebola viral disease received $\mathrm{CP}$ therapy on the early stage of illness (day 8 and 3 after symptom onset) and recovered without serious long-term sequelae to date (Kraft et al. 2015). One patient diagnosed with $\mathrm{H} 5 \mathrm{~N} 1$ received $\mathrm{CP}$ therapy on day 8 after symptom onset recovered and successfully discharged (Zhou et al. 2007). Thus, CP therapy might be an effective therapy for certain viral diseases, especially in early stage of illness.

However, to our knowledge, no reports about convalescent plasma therapy in viral disease at later stage have been published. Recently one case report suggests efficiency of CP therapy in treating 5 patients with severe
COVID-19 (Corman et al. 2020), the interval between the symptom onset and transfusion was $<20$ days. However, the interval in our study is much longer than the previously mentioned report. In our study, empirical anti-viral therapies were already implemented in these patients, but $\mathrm{Ct}$ value of respiratory tract specimens collected from these patients were still $<43$ before $\mathrm{CP}$ therapy, represented a high viral load. These patients with prolonged positivity of SARS-CoV-2 RNA [44.0 (30.0-47.0) days] still needed to hospitalize and separate, which may cause a huge cost during COVID-19 pandemic. In fact, individual human case studies reported long periods of viral shedding that 
Fig. 1 CT images before and after CP therapy. A Results of AI-assisted diagnostic system in patient 2 before CPT, blue areas represent GGO in CT images, red areas represent consolidation in CT images. B Results of AI-assisted diagnostic system in patient 2 after CPT. C Consolidation of $\mathrm{CT}$ in patients 1,2 , and 3 decreased after the transfusion. D GGO of CT in patients 1, 2, 3, 4 , and 5 decreased after $\mathrm{CP}$ therapy.
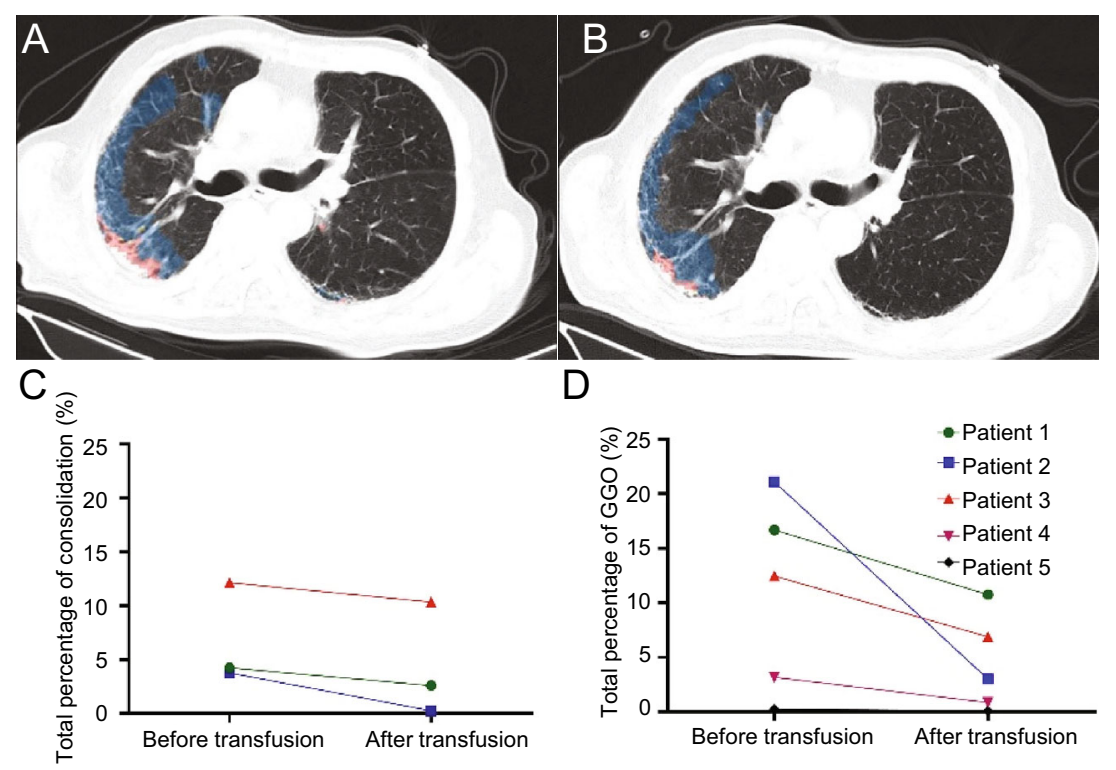

$\mathrm{D}$

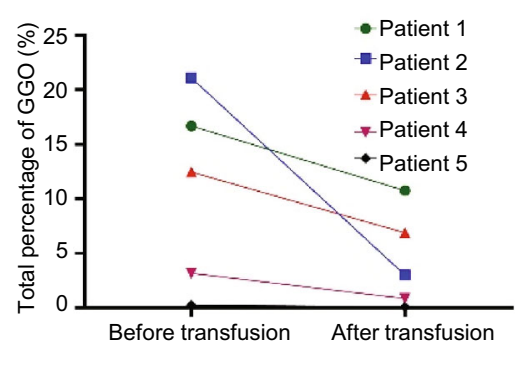

- ENG « LNG

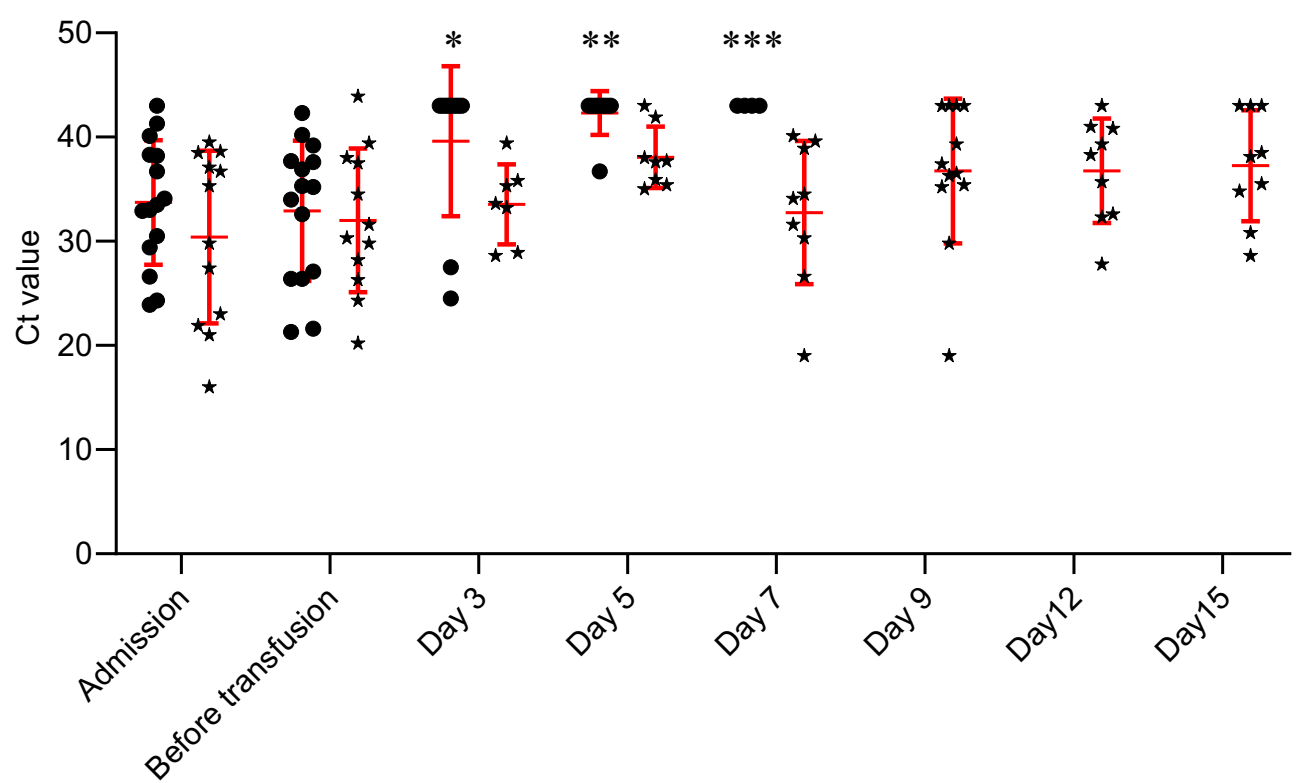

Fig. 2 Variation trend of viral load of patients before and after $\mathrm{CP}$ therapy: $\mathrm{Ct}$ value of $<43$ is defined to be positive, and $\mathrm{Ct}$ value of $>47$ would be undetectable. *The median $\mathrm{Ct}$ value in early negative group (ENG) was significantly greater than late negative group (LNG) on day 3 after the transfusion, $P=0.043$. **: The

in Middle East respiratory syndrome (MERS) pandemic (Kraaij-Dirkzwager et al. 2014; Spanakis et al. 2014). One report showed that 42-days positive test outcome in RTPCR assay of MERS in a healthcare worker in Saudi Araba (Al-Gethamy et al. 2015). Recently, a report have shown long-term coexisting of SARS-CoV-2 in some patients, and one of them did not produce any SARS-CoV-2-specific IgG with a positive test of SARS-CoV-2 in sputum after 46 days of illness (Wang B et al. 2020). No specific median $\mathrm{Ct}$ value in early negative group was significantly greater than late negative group on day $5, P=0.008$. ***: The median $\mathrm{Ct}$ value in early negative group was significantly greater than late negative group on day $7, P=0.003$.

therapies have proven to treat patients with prolonged positivity of SARS-CoV-2 RNA. In our study, more than half of the prolonged positive patients (EN group) met the discharge standard within 7 days and discharged rapidly after CP therapy. Thus, patients with prolonged positivity of SARS-CoV-2 RNA might benefit from CP therapy with shorter length of hospitalization and less cost. Besides, RTPCR of SARS-CoV-2 turned negative within 15 days after first infusion in five patients in LN group, one turned 
negative at 21 days, and six were still positive until the deadline.

Our research showed that the viral load of the respiratory tract specimen in two groups differed after CP therapy. Viral load may correlate with transmission potential in COVID-19 (Little et al. 2020). Recently, a report have shown viral load that was detected in the asymptomatic patient was similar to that in the symptomatic patients, which suggested the transmission potential of asymptomatic or minimally symptomatic patients (Zou et al. 2020). Besides, CP treatment may discontinue SARSCoV-2 shedding although didn't reduce mortality in critically end-stage COVID-19 patients (Zeng et al. 2020). In our study most patients might still remain transmission potential even though symptom were mild before $\mathrm{CP}$ therapy. Thus, implementing CP therapy in patients with prolonged positivity of SARS-CoV-2 RNA might help to decrease viral road and potential of transmission in our study.

In addition, Reports suggests the mortality of severe COVID-19 patients was more than $60 \%$ at 28 days (Yang $\mathrm{X}$ et al. 2020a, 2020b; Wang Z et al. 2020). Whether CP therapy can reduce mortality of patient with COVID-19 is unclear in our study. Symptoms of most patients in our study were mild, so we didn't do a mortality analysis. After CP therapy, three patients in LN group died in our study. We assumed that virus duration might be a vital reason of death in these three patients for their viral durations were quite long (59, 53, 53 days).

This study has several limitations. First, it is a retrospective observational study, a randomized double-blind trial would be more accurate to assess the efficacy of $\mathrm{CP}$ therapy in COVID-19. Second, symptoms of most patients in our study were mild, including more critically ill patients would be helpful in determining whether CP therapy could reduce mortality in COVID-19. Third, no studies have reported the appropriate time and dosage of $\mathrm{CP}$ implemented in patients with COVID-19; therefore, all decisions of CP therapy intervention were made by clinicians empirically. Forth, we did not monitor the neutralizing antibody in patients after CP therapy.

In conclusion, this retrospective observational study on CP therapy shows that patients with prolonged positivity of SARS-CoV-2 RNA can benefit from a rapid decrease of viral load and improvement in pulmonary images. The appropriate time to implement CP therapy and the optimal $\mathrm{CP}$ dosage are still to be explored in the future.

Acknowledgements This study was supported by the Fundamental Research Funds for the Central Universities (2020kfyXGYJ092).

Author Contributions YW, KH and LR collected the epidemiological and clinical data. XY, SP, JZ, JX, LC summarised all data.
YW, KH and LR drafted the manuscript. YS and $\mathrm{CH}$ revised the final manuscript and approved the manuscript.

\section{Compliance with Ethical Standards}

Conflict of interest The authors declare that they have no conflict of interest.

Animal and Human Rights Statement This study was approved by the ethical committee from Jinyintan Hospital. Written informed consent was waived due to the rapid emergence of this infectious disease.

\section{References}

Adair LB 2nd, Ledermann EJ (2020) Chest CT findings of early and progressive phase COVID-19 infection from a US patient. Radiol Case Rep 15:819-824

Ahn JY, Sohn Y, Lee SH, Cho Y, Hyun JH, Baek YJ, Jeong SJ, Kim JH, Ku NS, Yeom JS, Roh J, Ahn MY, Chin BS, Kim YS, Lee H, Yong D, Kim HO, Kim S, Choi JY (2020) Use of convalescent plasma therapy in two COVID-19 patients with acute respiratory distress syndrome in Korea. J Korean Med Sci 35:e149

Al-Gethamy M, Corman VM, Hussain R, Al-Tawfiq JA, Drosten C, Memish ZA (2015) A case of long-term excretion and subclinical infection with Middle East respiratory syndrome coronavirus in a healthcare worker. Clin Infect Dis 60:973-974

Cheng Y, Wong R, Soo YO, Wong WS, Lee CK, Ng MH, Chan P, Wong KC, Leung CB, Cheng G (2005) Use of convalescent plasma therapy in SARS patients in Hong Kong. Eur J Clin Microbiol Infect Dis 24:44-46

Chinese National Health Commission (2020) New coronavirus pneumonia prevention and control program. Accessed on http://www.nhc.gov.cn/yzygj/s7653pd/202003/056b2ce9e13142 e6a70ec08ef970f1e8.shtml

Corman VM, Landt O, Kaiser M, Molenkamp R, Meijer A, Chu DK, Bleicker T, Brünink S, Schneider J, Schmidt ML, Mulders DG, Haagmans BL, van der Veer B, van den Brink S, Wijsman L, Goderski G, Romette JL, Ellis J, Zambon M, Peiris M, Goossens H, Reusken C, Koopmans MP, Drosten C (2020) Detection of 2019 novel coronavirus (2019-nCoV) by real-time RT-PCR. Euro Surveill 25:2000045

Duan K, Liu B, Li C, Zhang H, Yu T, Qu J, Zhou M, Chen L, Meng S, $\mathrm{Hu} \mathrm{Y}$, Peng C, Yuan M, Huang J, Wang Z, Yu J, Gao X, Wang D, Yu X, Li L, Zhang J, Wu X, Li B, Xu Y, Chen W, Peng Y, Hu Y, Lin L, Liu X, Huang S, Zhou Z, Zhang L, Wang Y, Zhang Z, Deng K, Xia Z, Gong Q, Zhang W, Zheng X, Liu Y, Yang H, Zhou D, Yu D, Hou J, Shi Z, Chen S, Chen Z, Zhang X, Yang X (2020) Effectiveness of convalescent plasma therapy in severe COVID-19 patients. Proc Natl Acad Sci U S A 117:9490-9496

Hu X, Xing Y, Jia J, Ni W, Liang J, Zhao D, Song X, Gao R, Jiang F (2020) Factors associated with negative conversion of viral RNA in patients hospitalized with COVID-19. Sci Total Environ $728: 138812$

Hung IF, To KK, Lee CK, Lee KL, Chan K, Yan WW, Liu R, Watt CL, Chan WM, Lai KY, Koo CK, Buckley T, Chow FL, Wong KK, Chan HS, Ching CK, Tang BS, Lau CC, Li IW, Liu SH, Chan KH, Lin CK, Yuen KY (2011) Convalescent plasma treatment reduced mortality in patients with severe pandemic influenza A (H1N1) 2009 virus infection. Clin Infect Dis 52:447-456

Ivers LC, Walton DA (2020) Novel coronavirus disease (COVID-19): global health equity in pandemic response. Am J Trop Med Hyg 102:1149-1150 
Kirby T (2020) South America prepares for the impact of COVID-19. Lancet Respir Med 8:551-552

Kraaij-Dirkzwager M, Timen A, Dirksen K, Gelinck L, Leyten E, Groeneveld P, Jansen C, Jonges M, Raj S, Thurkow I, van Gageldonk-Lafeber R, van der Eijk A, Koopmans M, MERSCoV Outbreak Investigation Team of the Netherlands (2014) Middle East respiratory syndrome coronavirus (MERS-CoV) infections in two returning travellers in the Netherlands, May 2014. Euro Surveill 19:20817

Kraft CS, Hewlett AL, Koepsell S, Winkler AM, Kratochvil CJ, Larson L, Varkey JB, Mehta AK, Lyon GM 3rd, FriedmanMoraco RJ, Marconi VC, Hill CE, Sullivan JN, Johnson DW, Lisco SJ, Mulligan MJ, Uyeki TM, McElroy AK, Sealy T, Campbell S, Spiropoulou C, Ströher U, Crozier I, Sacra R, Connor MJ Jr, Sueblinvong V, Franch HA, Smith PW, Ribner BS; Nebraska Biocontainment Unit and The Emory Serious Communicable Diseases Unit (2015) The use of TKM-100802 and convalescent plasma in 2 patients with Ebola virus disease in the United States. Clin Infect Dis 61:496-502

Li N, Wang X, Lv T (2020) Prolonged SARS-CoV-2 RNA shedding: not a rare phenomenon. J Med Virol. https://doi.org/10.1002/ jmv. 25952

Little P, Read RC, Amlôt R, Chadborn T, Rice C, Bostock J, Yardley L (2020) Reducing risks from coronavirus transmission in the home-the role of viral load. BMJ 369:m1728

Liu WD, Chang SY, Wang JT, Tsai MJ, Hung CC, Hsu CL, Chang SC (2020) Prolonged virus shedding even after seroconversion in a patient with COVID-19. J Infect 81:318-356

Luke TC, Kilbane EM, Jackson JL, Hoffman SL (2006) Metaanalysis: convalescent blood products for Spanish influenza pneumonia: a future $\mathrm{H} 5 \mathrm{~N} 1$ treatment. Ann Intern Med 145:599-609

Saglietto A, D'Ascenzo F, Zoccai GB, De Ferrari GM (2020) COVID-19 in Europe: the Italian lesson. Lancet 395:1110-1111

Sahr F, Ansumana R, Massaquoi TA, Idriss BR, Sesay FR, Lamin JM, Baker S, Nicol S, Conton B, Johnson W, Abiri OT, Kargbo O, Kamara P, Goba A, Russell JB, Gevao SM (2017) Evaluation of convalescent whole blood for treating Ebola Virus Disease in Freetown, Sierra Leone. J Infect 74:302-309

Shen C, Wang Z, Zhao F, Yang Y, Li J, Yuan J, Wang F, Li D, Yang M, Xing L, Wei J, Xiao H, Yang Y, Qu J, Qing L, Chen L, Xu Z, Peng L, Li Y, Zheng H, Chen F, Huang K, Jiang Y, Liu D, Zhang Z, Liu Y, Liu L (2020) Treatment of 5 critically ill patients with COVID-19 with convalescent plasma. JAMA 323:1582-1589

Shi D, Wu W, Wang Q, Xu K, Xie J, Wu J, Lv L, Sheng J, Guo J, Wang K, Fang D, Li Y, Li L (2020) Clinical characteristics and factors associated with long-term viral excretion in patients with SARS-CoV-2 infection: a single center 28-day study. J Infect Dis 222:910-918

Spanakis N, Tsiodras S, Haagmans BL, Raj VS, Pontikis K, Koutsoukou A, Koulouris NG, Osterhaus AD, Koopmans MP, Tsakris A (2014) Virological and serological analysis of a recent Middle East respiratory syndrome coronavirus infection case on a triple combination antiviral regimen. Int $\mathbf{J}$ Antimicrob Agents 44:528-532

Walsh KA, Jordan K, Clyne B, Rohde D, Drummond L, Byrne P, Ahern S, Carty PG, O'Brien KK, O'Murchu E, O'Neill M, Smith SM, Ryan M, Harrington P (2020) SARS-CoV-2 detection, viral load and infectivity over the course of an infection: SARS-CoV2 detection, viral load and infectivity. J Infect 81:357-371

Wan R, Mao ZQ, He LY, Hu YC, Chen W (2020) Evidence from two cases of asymptomatic infection with SARS-CoV-2: are 14 days of isolation sufficient. Int J Infect Dis 95:174-175

Wang B, Wang L, Kong X, Geng J, Xiao D, Ma C, Jiang XM, Wang PH (2020) Long-term coexistence of SARS-CoV-2 with antibody response in COVID-19 patients. J Med Virol. https://doi. org/10.1002/jmv.25946

Wang Z, Yang B, Li Q, Wen L, Zhang R (2020) Clinical features of 69 cases with coronavirus disease 2019 in Wuhan, China. Clin Infect Dis 71:769-777

Yan D, Liu XY, Zhu YN, Huang L, Dan BT, Zhang GJ, Gao YH (2020) Factors associated with prolonged viral shedding and impact of Lopinavir/Ritonavir treatment in hospitalised noncritically ill patients with SARS-CoV-2 infection. Eur Respir J 56:2000799

Yang JR, Deng DT, Wu N, Yang B, Li HJ, Pan XB (2020) Persistent viral RNA positivity during the recovery period of a patient with SARS-CoV-2 infection. J Med Virol. https://doi.org/10.1002/ jmv. 25940

Yang X, Yu Y, Xu J, Shu H, Xia J, Liu H, Wu Y, Zhang L, Yu Z, Fang M, Yu T, Wang Y, Pan S, Zou X, Yuan S, Shang Y (2020a) Clinical course and outcomes of critically ill patients with SARS-CoV-2 pneumonia in Wuhan, China: a single-centered, retrospective, observational study. Lancet Respir Med $8: 475-481$

Yang X, Yang Q, Wang Y, Wu Y, Xu J, Yu Y, Shang Y (2020b) Thrombocytopenia and its association with mortality in patients with COVID-19. J Thromb Haemost 18:1469-1472

Zhang YC, Han S, Wang X, Shi X, Li Y, Yan J, Chen Y, Gu B (2020) Different longitudinal patterns of nucleic acid and serology testing results based on disease severity of COVID-19 patients. Emerg Microbes Infect 9:833-836

Zeng QL, Yu ZJ, Gou JJ, Li GM, Ma SH, Zhang GF, Xu JH, Lin WB, Cui GL, Zhang MM, Li C, Wang ZS, Zhang ZH, Liu ZS (2020) Effect of convalescent plasma therapy on viral shedding and survival in COVID-19 patients. J Infect Dis 222:38-43

Zhang B, Liu S, Tan T, Huang W, Dong Y, Chen L, Chen Q, Zhang L, Zhong Q, Zhang X, Zou Y, Zhang S (2020) Treatment with convalescent plasma for critically ill patients with SARS-CoV-2 infection. Chest 158:e9-e13

Zhou B, Zhong N, Guan Y (2007) Treatment with convalescent plasma for influenza A (H5N1) infection. N Engl J Med 357:1450-1451

Zhou B, She J, Wang Y, Ma X (2020) The duration of viral shedding of discharged patients with severe COVID-19. Clin Infect Dis. https://doi.org/10.1093/cid/ciaa451

Zhu N, Zhang D, Wang W, Li X, Yang B, Song J, Zhao X, Huang B, Shi W, Lu R, Niu P, Zhan F, Ma X, Wang D, Xu W, Wu G, Gao GF, Tan W, China Novel Coronavirus Investigating and Research Team (2020) China novel coronavirus investigating and research team. A novel coronavirus from patients with pneumonia in China, 2019. N Engl J Med 382:727-733

Zou L, Ruan F, Huang M, Liang L, Huang H, Hong Z, Yu J, Kang M, Song Y, Xia J, Guo Q, Song T, He J, Yen HL, Peiris M, Wu J (2020) SARS-CoV-2 viral load in upper respiratory specimens of infected patients. N Engl J Med 382:1177-1179 